\title{
МЕДІАСОФІЯ
}

Visn. Lviv. Univ., Ser. Zhurn. 2019: 46; 325-330 • DOI: http://dx.doi.org/10.30970/vjo.2019.46.10070

УДК 007:304:070

\section{(ВІД)ТВОРЕННЯ СВІТУ В МЕДІА: ПРАВО НА ІСТИНУ?}

\author{
Олена Семенець \\ Киїський університет імені Бориса Грінченка, \\ вул. Бульварно-Кудрявська, 18/2, 04053, Київ, Україна \\ e-mail: olenasemenets@gmail.com \\ https://orcid.org/0000-0003-2175-4859
}

Розкрито можливості застосування класичної та некласичної філософії в аналізі істиннісної природи медійних повідомлень. Визначено специфіку підходу модальної логіки і теорії можливих світів в оцінці істинності повідомлень. У прикладному аспекті запропоновано шляхи розв'язання проблеми істинності з позицій реципієнта медійних повідомлень.

Ключові слова: істина, дискурс медіа, кореспондентна та когерентна теорії істини, модальна логіка, можливі світи.

Постановка проблеми. Доба постмодерну, разом 3 переходом до мультимедійної електронної культури, спричинила проблематизацію поняття істини та об'єктивності змісту повідомлення. Новітній медійний світ сповнений поліфонії голосів і плюралізму думок, при цьому в цифровому комунікаційному середовищі зростають ризики впливу маніпуляційних технологій. Це загострює відчуття непевності, хисткості та багатовимірності самого поняття істини.

Наскільки взагалі можна говорити про «чисті факти» та про об'єктивність їх відтворення в мас-медіа? Адже ця сфера побудована за міркою людини, залежна від людських інтерпретацій і у своєму функціонуванні спрямована на взаємодію зі свідомістю, особистою та масовою.

У новітньому комунікаційному середовищі зростає конкуренція за «право на істину» між професійними медіа та, з другого боку, альтернативними медіа, соціальними мережами та блогами, які позиціонують себе як неупереджені, позбавлені корисних мотивів, мотивовані почуттям громадянського обов'язку.

Проблема якості масовоінформаційного простору та соціальної відповідальності діячів медійної сфери обговорюється на всіх рівнях суспільства: від споживачів інформації, представників фахового журналістського середовища, освіти й науки до владних структур. У Франції, наприклад, розроблено законопроект про фейкові новини та обговорюється ініціатива запровадження сертифікатів правдивості інформації, що їх згодом зможуть розміщувати як медіа, так і окремі журналісти і навіть

$\overline{\text { (C) Семенець O., } 2019}$ 
блогери. У такий спосіб якісні медіа прагнуть відновити частково втрачену довіру аудиторії та запобігти масовим маніпуляціям [1].

Аналіз останніх досліджень 3 проблематики роботи. Проблема істинності та об'єктивності змісту медійних повідомлень становить предмет уваги різних напрямів гуманітарних наук: філософії [2-5], дискурс-аналізу [6-9], теорії комунікації [10-12], журналістикознавства [13]. Медіафілософський підхід у зазначеній проблематиці постає як міждисциплінарний напрям, який бере до уваги здобутки досліджень гуманітарних наук, враховує сутність досліджуваного об'єкта (повідомлення в аспекті його істинності) та середовища його функціонування (сфери медіа).

Мета дослідження - з'ясувати можливості класичної та некласичної філософії в аналізі істиннісної природи медійних повідомлень.

Завдання дослідження:

- розкрити можливості застосування різних філософських концепцій істини в аналізі медійних повідомлень;

• визначити специфіку підходу модальної логіки і теорії можливих світів в оцінці істинності висловлень;

- у прикладному аспекті - запропонувати шляхи розв'язання проблеми істинності з позицій реципієнта медійних повідомлень.

Відомі концепції істини класичної філософії встановлюють сутність цього поняття у зв’язку з відповідністю фактам емпіричної дійсності (кореспондентна теорія істини) або смислової узгодженості компонентів можливого світу (когерентна теорія істини). Тоді цілком логічним було б в оцінці дискурсу presse d'information спиратися на кореспондентну теорію істини (головний критерій - відповідність змісту висловлення фактам емпіричної дійсності), а для сучасної presse d'opinion з її суб'єктивністю інтерпретацій найбільш релевантною виявилася б когерентна теорія істини (основний критерій - смислова узгодженість компонентів можливого світу).

Проте й presse d'information неминуче вибудовує свої можливі світи під значним впливом суб'єктивних чинників - самого відбору фактів для повідомлення (модель «gatekeeper» Курта Левіна), повторенням меседжів, впливом контексту, дискурсивних практик тощо.

3 погляду логічної семантики, засади побудови різних логічних систем можуть бути пов'язані зі специфікою об’єктів універсуму розгляду (чинників онтологічного спрямування), а також можуть визначатися концептуальним апаратом суб'єкта пізнання - самими поняттями істинності, хибності, логічного випливання, що приймаються як базові. Відповідно до цих двох типів теоретико-пізнавальних передумов О. Д. Смирнова розмежовує два типи логічних законів: закони власне логіки, що є залежними від об’єктів універсуму розгляду, - та закони металогіки, пов’язані 3 поняттями істини, хиби, судження, тобто закони, які визначаються раціональними функціями суб'єкта пізнання, здатністю судження та висновку. При цьому дослідниця - очевидно, в руслі загальної тенденції релятивізації наукового знання - показує можливість побудови логічних семантик на грунті визнання відносності й змінності законів металогіки, коли беруть за основу поняття частково визначених предикатів істинності та хибності і виходять з ідеї симетрії, тобто незалежності, понять істини та хиби (відповідно змінюється й розуміння логічного випливання) [14].

На противагу стандартній логічній семантиці, у модальній логіці оперують поняттями об’єктів різного роду: розглядаються як об'єкти реального світу, так i 
об'єкти можливих світів. Семантика можливих світів як окрема логіко-філософська дисципліна була побудована в 1950-1960-ті роки незалежно С. Кангером, С. Кріпке, Р. Монтегю, Я. Хінтіккою та іншими логіками. Важливо, що під можливим світом у логічній семантиці розуміють світ, можливий відносно певної мови (природної або штучної, формалізованої). Фінський логік Я. Хінтікка наполягає не лише на тому, що завжди йдеться про певну множину світів, якими задається семантика мови. Не менш важливе й те, що число й характер цих світів задаються межами мови. Самі можливості виявляються можливостями мовними.

Можливий світ має дискурсивний, або текстуальний, характер і становить особливий спосіб опису ситуацій чи подій реальності. I саме поняття істинності в окремих можливих світах пов'язане з дискурсивною природою повідомлень: «Дискурс існує насамперед і головним чином у текстах, але таких, за якими постає особлива граматика, особливий лексикон, особливі правила слововживання й синтаксису, особлива семантика, - в кінцевому підсумку - особливий світ. У світі кожного дискурсу діють свої правила синонімічних замін, свої правила істинності, свій етикет. Це «можливий (а л ь т е р н а т и в н и й) світ» у повному сенсі цього логіко-філософського терміна. Кожен дискурс - це один з «можливих світів» [15, с. 44-45].

3 погляду модальної логіки, істиннісну сутність висловлень або предикатів визначає алетична модальність, операторами якої $є$ «логічно необхідне», «логічно випадкове», «логічно можливе», «логічно неможливе». Алетичний оператор «логічно можливе» задає, наприклад, різні інтерпретації події, що артикулюються різними 3MI, позиція яких, в аспекті прагматики, зумовлена власниками, редакційною політикою, впливом тих чи інших політичних та бізнесових кіл. Різні інтерпретації однієї події - це, з позицій алетичної модальної логіки, різні її описи в побудованих «можливих світах».

Істинність (тобто логічна валентність) висловлення в медійному дискурсі великою мірою залежить від прагматичних факторів, які задають параметри побудованого в конкретному повідомленні ЗМІ можливого світу.

Збалансованість впливу на реципієнта значною мірою мусить бути забезпечена системним оточенням великої кількості різноманітних 3МI, які дають змогу висвітлювати різні події, висловлювати різні думки у зв'язку з конкретною проблемою.

Проте замкнутість ЗМІ на самореференції, тобто відсилання системи до самої себе (Н. Луман), передбачає, що ця система комунікації по суті відмовляє зовнішнім інстанціям у праві на визначення істини та встановлення оцінок. Подібна ознака операційної замкнутості певною мірою наявна і в аудиторії медіа, адже для реципієнта важливо передусім, наскільки «можливий світ» медійного повідомлення узгоджується з його власною системою знань, цінностей і переконань, і саме це впливає на оцінку істиннісної природи повідомлень.

Чи взагалі можливий при цьому конструктивний діалог між ЗМI, які належать до різних медіахолдингів? Згадаймо Ж.-Ф. Ліотара: «Консенсус став застарілою цінністю, він підозрілий. Однак справедливість до таких не належить. Отже, треба йти до ідеї й практики справедливості, яка не була б прив'язана до консенсусу» [16, с. 157].

Філософська парадигма постмодернізму тлумачить істину і знання як множинні, контекстуальні та історично сформовані через дискурси. Трансформації постмодерної свідомості віддзеркалені в словах і поняттях, що виникають і актуалізуються в новітню добу. 
У 2005 році Американська лінгвістична асоціація назвала ключовим поняттям, яке визначає характер сучасного суспільства, truthiness («правдоподібність»), що його лінгвісти визначають як «властивість, притаманну сформульованій концепції, яку індивідуум приймає або воліє приймати за дійсність замість того, щоб вірити фактам».

А словом 2016 року, згідно з Оксфордським словником, стає post-truth («постправда») - на позначення феномену, що виникає в результаті впливу численних джерел інформації, безлічі позірно правдивих висловлень, істинність яких потребує з'ясування.

Філософія постмодернізму, замість обговорення проблеми істинності висловлень, зосереджується на самому тексті, дискурсі як самодостатній реальності. Істина при цьому виступає як певний «ефект» когнітивного вольового зусилля, і релевантними виявляються передусім відношення влади в дискурсі (М. Фуко).

У маніпулятивному дискурсі зловживання владою означає «порушення фундаментальних норм і цінностей в інтересах тих, у кого є влада, та проти інтересів інших людей» [17, с. 37]. I саме з'ясування форм і способів нелегітимного керування свідомістю та контролю над діями людей в аспекті відтворення влади становить завдання критичних дискурсивних досліджень, за визначенням Т. ван Дейка [17, с. 26].

Висновки. Особлива роль у розв'язанні проблеми встановлення істинності висловлення належить розвитку рефлексивної свідомості та вихованню інформаційної, громадянської, моральної, психологічної культури медійної аудиторії.

Людина постмодерної доби вчиться жити плюралістично, у багатьох можливих світах водночас, вчиться шукати істину, вслухаючись у багатоголосся мультимедійного середовища, спираючись на відчуття правди й справедливості. Майбутнє за людиною, яка мислить нелінійно. 3 погляду синергетики, відкритість ментальної системи людини передбачає наявність у ній джерел та стоків у процесі інформаційно-енергетичного обміну з навколишнім середовищем.

Цікавими видаються візуальні образи, що допомагають зрозуміти синергетичну природу систем, які самоорганізуються. О. М. Князєва та С. П. Курдюмов зазначають, що для таких систем мусить існувати не точкове, локалізоване джерело (як, наприклад, джерело, з якого починається струмок або ріка) - навпаки, необхідні так звані об'ємні джерела та стоки інформації, що мають місце в кожній точці системи. Прикладом можуть слугувати два середовища, які тісно прилягають одне до одного й проникають одне одного у своїй взаємодії: кора головного мозку, пронизана кровоносними судинами, які живлять мозок; або ж місто з його своєрідною «кровоносною системою» - розгалуженою інфраструктурою транспорту й зв'язку, що забезпечує життєдіяльність міста в кожній його точці [18, с. 42-43].

Людина має бути відкрита до безлічі «об'ємних» джерел інформації, повинна вміти порівнювати, зважувати, критично оцінювати численні повідомлення, які надходять, формувати власне бачення подій та оцінку фактів. Необхідно формувати в сучасної людини здатність до стереоскопічного сприймання інформації. Саме це забезпечуватиме синергетичну вбудованість когнітивної системи людини в навколишній світ, що стрімко змінюється, в тому числі й у світ медіа.

Перспективи подальших досліджень, зокрема в напрямі критичного дискурс-аналізу, пов’язані з розкриттям механізмів дискурсивного домінування, «ефектів влади», представлених у медійному дискурсі, а також закономірностей «вироблен- 
ня» істини в дискурсивних практиках медіасфери; важливо також удосконалювати способи формування медійної культури аудиторії.

\section{REFERENCES}

1. Лазарева А. Законопроект про фейкові новини. [Електронний ресурс]. Режим доступу: http://medialab.online/news/france/

2. Фуко М. Воля к истине: по ту сторону знания, власти и сексуальности. Работы разных лет. М. : Касталь, 1996. 448 с.

3. Бодрийяр Ж. К критике политической экономии знака. М. : Академический Проект, 2007. 335 с.

4. Бодрийяр Ж. Символический обмен и смерть. М. : Добросвет, 2000. 387 с.

5. Ліотар Ж. Ф. Що є істина? // «Ї» : Незалежний культурологічний часопис. 2003. Число 30. [Електронний ресурс]. Режим доступу: http:/www.ji.lviv.ua/n30texts/ liotar.htm

6. Fairclough N. Analysing Discourse: Textual analysis for social research. London: Routledge, 2003. 270 p.

7. Van Dijk T. A. Society and Discourse: How Social Contexts Influence Text and Talk. Cambridge : Cambridge University Press, 2009. 287 p.

8. Van Dijk T. A. Discourse and Power. Contributions to Critical Discourse Studies. New York: Palgrave MacMillan, 2008. 308 p.

9. Angermuller J. Truth after post-truth: for a Strong Programme in Discourse Studies // Palgrave Communications. Vol. 4. Avaible at: https://www.nature.com/articles/s41599018-0080-1\#auth-1

10. Георгий Почепцов: Если фейк не является сознательным обманом, это тоже истина. [Электронный ресурс]. Режим доступа: https://fraza.ua/interview/267640georgij-pocheptsov-esli-fejk-ne-javljaetsja-soznatelnym-obmanom-eto-tozhe-istina-

11. Георгий Почепцов: Сегодняшний мир столкнулся с новой технологией - «множественностью правд». [Электронный ресурс]. Режим доступа: https:/hvylya.net/ analytics/tech/y-mir-stolknulsya-s-novoy-tehnologiey-mnozhestvennostyu-pravd.html

12. Почепцов Г. Фейки и потеря правды. [Электронный ресурс]. Режим доступа: https://ms.detector.media/trends/1411978127/feyki_i_poterya_pravdy/

13. Михайлин I. Природа факту в площині журналістики // Збірник Харківського історико-філологічного товариства: Нова серія. 2011. Том 14. С. 121-138.

14. Смирнова Е. Д. Истинность и вопросы обоснования логических систем // Исследования по неклассическим логикам (VI Советско-финский коллоквиум) / Отв. ред. В. А. Смирнов. М. : Наука, 1989. С. 150-164.

15. Степанов Ю. С. Альтернативный мир, Дискурс, Факт и принцип Причинности // Язык и наука конца 20 века / Под ред. акад. Ю. С. Степанова. М. : Рос. гос. гуманит. ун т, 1995. С. 35-73.

16. Лиотар Ж. Ф. Состояние постмодерна. М. : Институт экспериментальной социологии; Спб. : Алетейя, 1998. 160 с.

17. Ван Дейк Т. А. Дискурс и власть: Репрезентация доминирования в языке и коммуникации. М. : Книжный дом «ЛИБРОКОМ», 2013. 344 с.

18. Князева Е. Н., Курдюмов С. П. Основания синергетики. Синергетическое мировидение. М. : КомКнига, 2005. 240 с. 


\title{
(RE)CONSTRUCTING WORLD IN MEDIA: THE RIGHT TO TRUTH?
}

\author{
Olena Semenets \\ Borys Grinchenko Kyiv University, \\ 18/2 Bulvarno-Kudriavska Str, 04053, Kyiv, Ukraine \\ e-mail: olenasemenets@gmail.com \\ https://orcid.org/0000-0003-2175-4859
}

During the transition to multimedia e-culture the concepts of truth and objectivity are problematizing sharply. Postmodern relativized media world is filled with polyphony of voices and pluralism of opinions. It exacerbates feeling of multidimensionality as well as uncertainty and fragility of truth. Especially that concerns sphere of mass media and patterns of real events formed in it.

Is it possible to speak of «pure facts» and their objective presentation in mass media at all? Because that sphere is based on the measure of person, depends on human mind and in its function it's aimed at interaction with personal and public consciousness.

The media-philosophical approach in analysis of truth and objectivity of content of media messages takes into account achievements of various fields of the humanities: philosophy, discourse analysis, communication theory, journalism. It considers the essence of the studied object (the message in terms of its truth) and the environment of its functioning (media sphere).

The article describes the possibilities of applying classical and non-classical philosophy in analysis of true nature of media messages. In particular, heuristic possibilities of well-known concepts of truth in classical philosophy such as correspondent and coherent theories of truth are analyzed. The specificity of the approaches of modal logic and the theory of possible worlds in assessing truth of messages is determined.

In the applied aspect, ways of solving the problem of truth from the positions of the recipient of media messages are proposed. Importance of reflexive thinking and respect for pluralism of thoughts is emphasized. In the aspect of synergetics, importance of developing non-linear thinking of the recipient of media messages, openness to numerous «voluminous» sources of information is emphasized.

Key words: truth, media discourse, correspondence and coherent theories of truth, modal logic, possible worlds. 